\title{
Mitigasi Risiko Pembiayaan Pada Bank Perkreditan Rakyat Syariah (BPRS) SAFIR Cabang Curup Kabupaten Rejang Lebong
}

\author{
Ika Gustin Rahayu \\ Institut Agama Islam Negeri (IAIN) Curup \\ E-mail: ikadusuncurup@gmail.com \\ Hendrianto \\ Institut Agama Islam Negeri (IAIN) Curup \\ E-mail: hendrianto9909@gmail.com
}

\begin{abstract}
Increasingly better risk mitigation will help realize the objectives of the BPRS, namely to improve the economy of the lower middle class. BPRS as one of the microfinance institutions must be faced with risks, especially financing risks. The purpose of this study is to find out the risk mitigation actions carried out by BPRS SAFIR in order to minimize risks properly. This research is a field research (field research) that uses a qualitative approach withmethod descriptive analysis. Data collection used is interviews with accounting staff and secondary data from the literature related to risk in BPRS. The analysis technique used is to classify the data obtained with each category which is then analyzed. The results of this study are: There are several stages of financing procedures at BPRS SAFIR, first is the submission of a financing application, the second is submission of the file to the Account Officer; Third initial survey by the Account Officer in charge, Fourth follow-up survey with several Account Officers; The five decisions on funding by branch managers, the sixth realization decision. The financing risk faced by BPRS SAFIR is credit risk and strategic risk, these two risks are also prioritized by BPRS $S A F I R$ because they are caused by both partners. The mitigation measures of BPRS SAFIR in reducing risk are carried out by:First, establishing certain conditions for each financing that must be met by prospective recipients of financing facilities. The two binding guarantees are fixed assets and movable assets. Third, do monitoring periodic.
\end{abstract}

Keywords: Mitigation, Risk, Financing, BPRS, Financing Procedure, and Customers

\begin{abstract}
Abstrak
Mitigasi risiko yang semakin baik akan membantu mewujudkan tujuan BPRS, yaitu meningkatkan perekonomian masyarakat menengah ke bawah. BPRS sebagai salah satu lembaga keuangan mikro pasti dibadapkan dengan risiko, terutama risiko pembiayaan. Adapun tujuan dari penelitian ini adalah untuk mengetahui tindakan mitigasi risiko yang dilakukan BPRS SAFIR agar dapat meminimalisir risiko dengan baik. Penelitian ini merupakan penelitian lapangan (field research) yang
\end{abstract}

Al Falah: Journal of Islamic Economics, Vol. 3, No. 2, 2018

STAIN Curup|E-ISSN: 2548-3102, P-ISSN: 2548-2343

Available online: http://journal.staincurup.ac.id/index.php/alfalah 
menggunakan pendekatan kualitatif dengan metode deskriptif analisis. Pengumpulan data yang digunakan adalah wawancara dengan staff accounting dan data sekunder dari literatur-literatur yang berkaitan dengan risiko di BPRS. Teknik analisis yang digunakan adalab mengklasifikasikan data yang didapat dengan kategorinya masing-masing yang kemudian dianalisis. Hasil dari penelitian ini adalah: Prosedur pembiayaan pada BPRS SAFIR ada beberapa tahap, Pertama pengajuan permohonan pembiayaan, Kedua penyerahan berkas ke Account Officer; Ketiga survei awal oleh Account Officer yang bertanggung jawab, Keempat survei lanjutan dengan beberapa Account Officer; Kelima keputusan pemberian pembiayaan oleh pimpinan cabang, Keenam realisasi keputusan. Risiko pembiayaan yang dibadapi oleh BPRS SAFIR ialah risiko kredit dan risiko strategik, kedua risiko ini juga diutamakan oleh BPRS SAFIR karena disebabkan oleh kedua pihak yang bermitra. Langkah tindakan mitigasi BPRS SAFIR dalam mengurangi risiko dilakukan dengan:Pertama, penetapan syarat-syarat tertentu untuk masing-masing pembiayaan yang harus dipenubi calon nasabah penerima fasilitas pembiayaan.Kedua pengikatan jaminan berupa fixed asset dan movable asset. Ketiga, melakukan monitoring berkala.

Kata Kunci : Mitigasi, Risiko, Pembiayaan, BPRS, Prosedur Pembiayaan, dan Nasabah

\section{PENDAHULUAN}

Seluruh aktivitas bank mulai dari pengumpulan dana hingga penyaluran dana sangat rentan terhadap risiko terutama risiko kehilangan uang, khususnya dalam hal pembiayaan yang dilakukan kepada nasabah pasti terdapat berbagai kendaladan masalah yang dihadapi ${ }^{1}$.

Pembiayaan merupakan sebagian besar aset dari bank syariah sehingga pembiayaan tersebut harus dijaga kualitasnya, sebagaimana diamanatkan pada Pasal 2 Undang-undang Perbankan Syariah bahwa perbankan syariah dalam melakukan kegiatan usahanya berasaskan prinsip syariah, demokrasi ekonomi dan prinsip kehati-hatian.

Pada penjelasan Pasal 2 Undang-Undang Perbankan Syariah yang dimaksud dengan prinsip kehati-hatian adalah pedoman pengelolaan bank yang wajib dianut guna mewujudkan perbankan yang sehat, kuat dan efisien sesuai dengan ketentuan peraturan perundang-undangan. Prinsip kehati-hatian adalah pengendalian risiko melalui penerapan peraturan perundang-undangan dan ketentuan yang berlaku secara konsisten. ${ }^{2}$

Risiko yang mungkin terjadi dapat menimbulkan kerugian bagi bank jika tidak dideteksi serta tidak dikelola sebagaimana mestinya. Untuk itu, bank harus mengerti dan mengenal risiko-risiko yang mungkin timbul dalam melaksanakan

${ }^{1}$ Risa Safariyani, Manajemen Risiko Pembiayaan Al-Istishna' Pada BPRS Amanab Ummah, Leuwiliang Bogor, Skripsi Fakultas dan Hukum UIN Syarif Hidayatullah

2Trisadini Prasastinah Usanti, Pengelolaan Risiko Pembiayaan di Bank Syariah, (Fakultas Hukum Airlangga, Vol.3 No.2), hal. 409 
kegiatan usahanya yang dikenal dengan manajemen/mitigasi risiko. Pengelolaan risiko pembiayaan merupakan hal utama yang paling penting.

Keberlangsungan usaha bank syariah. Risiko yang dihadapi bank syariah perlu dikelola secara tepat karena kesalahan dalam pengelolaannya dapat berdampak pada NPF (Non Performing Financing). Tingginya tingkat NPF akan berpengaruh pada menurunnya pendapatan yang diterima oleh Bank dan bagi hasil yang diterima oleh para deposan bank syariah tersebut. ${ }^{4}$

Risiko pembiayaan adalah risiko yang disebabkan oleh adanya kegagalan counterparty dalam memenuhi kewajibannya. ${ }^{5}$ Dalam bank syariah risiko terkait pembiayaan ada dua, yaitu risiko internal dan eksternal. Risiko internal ialah risiko yang berasal dari produk bank sendiri, dan risiko eksternal yang berasal dari nasabah.

Penulis telah melakukan survei awal untuk mengetahui bagaimana tindakan pengelolaan risiko.Situasi lingkungan baik internal maupun eksternal perbankan selalu mengalami perkembangan pesat yang diikuti dengan semakin kompleksnya risiko kegiatan uasaha perbankan sehingga meningkatkan kebutuhan praktik tata kelola bank yang sehat (good corporate governance) dan penerapan manajemen risiko yang meliputi pengawasan aktif pengurus bank, kebijakan, prosedur dan penetapan limit risiko, proses identifikasi, pengukuran, sistem informasi, dan pengendalian risiko, serta pengendalian intern. ${ }^{6}$

Risiko yang bersumber dari internal bank ialah faktor yang paling besar memiliki andil dalam keberlangsungan usaha sebuah bank. Salah satu risiko yang bersumber dari internal bank ialah terjadinya kesalahan pada identifikasi nasabah pembiayaan, dan lemahnya sistem monitoring/pengawasan pada pembiayaan.

Pada sisi aktiva neraca bank syariah bagian terbesar dana operasionalsetiap bank syariah disalurkan dalam bentuk pembiayaan. Kenyataan ini menggambarkan bahwa pembiayaan adalah sumber pendapatan bank yang terbesar, namun sekaligus merupakan sumber risiko operasi bisnis yang terbesar. Pembiayaan bermasalah bahkan menjadi kategori macet menjadi masalah bagi bank syariah, karena dengan adanya pembiayaan bermasalah bukan saja menurunkan pendapatan bagi bank syariah tetapi juga menggerogoti jumlah dana operasional dan likuiditas keuangan bank syariah, yang akhirnya akan menggoyahkan kesehatan bank syariah dan pada akhirnya akan merugikan

${ }^{3}$ Ibid., hal. 22

${ }^{4}$ Ibid., hal. 8

${ }^{5}$ Adiwarman Karim, Bank Islam (Analisis Figh dan Keuangan), (Jakarta: PT Raja Grafindo Persada, 2004), hal.260

${ }^{6}$ Veithzhal Rivai, Sofyan Basir, dkk, Commercial Bank. Management (Manajemen Perbankan) Dari Teori ke Praktik, (Jakarta: PT. Raja Grafindo Persada, 2012), hal.549 
nasabah penyimpan/nasabah investor. Pembiayaan bermasalah merupakan bagian yang tidak bisa dihindari dalam proses pembiayaan. Risiko dari pemberian pembiayaan ini ialah pengembalian yang tertunda atau ketidakmampuan peminjam dalam membayar yang telah dibebankan. ${ }^{7}$

Pembiayaan bermasalah ialah salah satu indikator kunci untuk menilai kinerja bank. Menurut Pernyataan Standar Akuntansi Keuangan (PSAK) No 31 (Revisi 2000), disebutkan bahwa kredit atau pembiayaan bermasalah adalah kredit yang pembayaran pembayaran angsuran pokok dan/atau bunganya telah lewat 90 hari setelah jatuh tempo, atau kredit yang pembayarannya secara tepat waktu sangat diragukan. NPF secara luas dapat di definisikan sebagai suatu kredit dimana pembayaran yang dilakukan macet atau tidak mencukupi kewajiban minimal yang ditetapkan sampai dengan kredit yang sulit untuk dilunasi atau bahkan tidak dapat ditagih.

Penerapan pengelolaan risiko akan memberikan manfaat, baik kepada perbankan ataupun otoritas pengawasan bank. Esensi dari penerapan pengeloaan risikoadalah kecukupan prosedur dan metodologi pengelolaan risiko sehingga kegiatan usaha bank tetap dapat terkendali (manageable) pada batas/ limit yang dapat diterima serta menguntungkan bank.

Namun demikian, mengingat perbedaan kondisi pasar, struktur, ukuran serta kompleksitas usaha bank, maka tidak terdapat satu sistem manajemen risiko yang universal untuk seluruh bank sehingga setiap bank harus membangun system manajemen risiko sesuai dengan fungsi dan organisasi manajemen risiko pada bank. ${ }^{8}$

Berdasarkan uraian di atas kemudian setelah melakukan BPRS sangat rentan akan risiko yang ditimbulkan dari pembiayaan yang diberikan. Dengan demikian penulis tertarik untuk menulis tentang mitigasi risiko pembiayaan yang dilakukan oleh Bank Perkreditan Rakyat Syariah (BPRS) SAFIR tersebut.

\section{METODE PENELITIAN}

Penelitian ini penulis menggunakan Jenis dan metode penelitian adalah penelitian lapangan (Field Research) dengan pendekatan kualitatif. Metode yang digunakan adalah metode deskriptif analisis, yaitu penulis mengambarkan datadata yang ada, kemudian dianalisis lebih lanjut untuk ditarik kesimpulan.

Objek Penelitian lokasi penelitian yaitu Bank Perkreditan Rakyat Syariah (BPRS) SAFIR Cabang Curup Kabupaten Rejang Lebong yang terletak di

7 Muhammad, Manajemen Pembiayaan Bank Syariah, (Yogyakarta: Unit Penerbit dan Percetakan, 2005), hal. 168

${ }^{8}$ Ibid., hal. 700 
Sukawati, adapun alasan penelitian ini dilaksanakan di Bank Perkreditan Rakyat Syariah (BPRS) SAFIR Cabang Curup Kabupaten Rejang Lebong dalam tindakan mitigasi risiko pembiayaan yang dilakukan serta kesesuainnya dengan Standar Operasional Prosedur yang ada. Dan juga untuk memberikan pengetahuan tentang BPRS kepada masyarakat yang masih sangat sedikit dari masyarakat Kabupaten Rejang Lebong yang mengetahui BPRS SAFIR di wilayah Curup ini. Sumber dan Teknik Pengumpulan Data Bahan acuan (sumber) dalam penelitian ini penulis membagi dalam 2 kategori, yaitu data primer dan data sekunder.

Data primer data yang diperoleh langsung dari pihak BPRS SAFIR, berupa hasil interview (wawancara) secara langsung yang telah dipersiapkan sebelumnya dengan pihak BPRS SAFIR Cabang Curup Kabupaten Rejang Lebong yang berkaitan dengan pembahasan skripsi ini. Data sekunder data yang diperoleh dari laporan-laporan atau data-data yang dikeluarkan dan literaturliteratur kepustakaan seperti buku-buku, serta sumber lainnya yang berkaitan dengan pembahasan skripsi ini. Untuk memperoleh data yang akurat, maka penulis menggunakan metode sebagai berikut: Studi Kepustakaa Metode ini digunakan untuk memperoleh data dari sumber-sumber bacaan, seperti: buku, internet, dan lain-lain.

Observasi untuk mendapatkan data yang aktual secara langsung maka observasi lapangan sangat diperlukan. Observasi adalah teknik pengumpulan data dimana pihak peneliti melakukan pangamatan tentang hal-hal yang akan diteliti. Dalam hal ini yang menjadi objek penelitian adalah Bank Perkreditan Rakyat Syariah (BPRS) SAFIR Cabang Curup Kabupten Rejang Lebong. Wawancara adalah suatu cara pengumpulan data yang digunakan untuk memperoleh informasi secara langsung dari sumbernya. Wawancara ini digunakan bila ingin mengetahui hal-hal dari responden secara lebih mendalam serta jumlah responden yang sedikit. Ada beberapa faktor yang akan mempengaruhi arus informasi dalam wawancara, yaitu: pewawancara, responden, pedoman wawancara, dan situasi wawancara. Dokumentasi adalah ditujukan untuk memperoleh data langsung dari tempat penelitian, meliputi buku-buku yang relevan, peraturan-peraturan, laporan kegiatan, foto-foto, dan data penelitian yang relevan. Teknik Analisis Datayang telah didapatkan dengan metode di atas dianalisis dan diklasifikasikan sesuai dengan kategorinya masingmasing baru kemudian diadakan analisis data. Analisis data yang digunakan dalam penelitian ini adalah analisis kualitatif, dengan analisa non statistik yang tidak dapat diukur dengan angka. Namun, karena penelitian ini bersifat deskriptif, maka penelitian ini bersifat menggambarkan realita yang ada. 


\section{HASIL DAN PEMBAHASAN}

\section{Prosedur Pemberian Pembiayaan Pada BPRS SAFIR Cabang Curup Kabupaten Rejang Lebong}

Dalam kegiatan operasional, BPRS SAFIR didukung oleh produk penghimpunan dana serta produk penyaluran dana. Produk penyaluran dana yang dalam hal ini disebut pembiayaan, dilakukan antara bank dengan nasabah yang bermitra dengan memberikan kontribusi baik berupa dana ataupun jasa. Pada BPRS SAFIR produk pembiayaan ada 3, yaitu pembiayaan Murabahah, pembiayaan Musyarakah, dan pembiayaan Ijarah multijasa. Pada umumnya proses pembiayaan yang dilakukan pada ketiga pembiayaan ini sama, tergantung dengan kebutuhan dan tujuan nasabah.

Untuk prosedur pembiayaan di BPRS SAFIR tidak terlalu rumit dan bertele-tele, jika calon nasabah penerima fasilitas sudah menyerahkan berkas ke Account Officer atau Costomer Service, kami akan langsung menindaklanjuti. Meskipun demikian ada tahap-tahap yang harus dilewati untuk menyetujui pembiayaan yang diajukan.

Berdasarkan hasil wawancara di atas, prosedur pembiayaan dirasa sangat penting dilakukan dengan benar agar tidak ada risiko besar yang muncul dikemudian hari. Dengan adanya prosedur pembiayaan, calon nasabah penerima fasilitas pasti akan terseleksi dengan baik jika semua syarat-syarat yang ditetapkan sudah dipenuhi. Prosedur pembiayaan merupakan langkah awal untuk memproteksi bank dari ancaman risiko yang ada.

\section{Langkah-langkah Pengajuan Pembiayaan Pada BPRS SAFIR}

a. Permohonan Pembiayaan merupakan tahap awal yang dilakukan oleh calon nasabah penerima fasilitas pembiayaan dengan menyertakan syarat-syarat dalam satu dokumen. Pada tahap ini juga bank bisa mengenali calon nasabah penerima fasilitas melalui pemenuhan syarat yang diajukan. Pada awal pengajuan permohonan pembiayaan, nasabah bisa datang sendiri ke bank dengan membawa persyaratan lengkap yang ada di brosur ataupun nasabah bisa menyerahkan langsung ke Account Officer. ${ }^{10}$

Nasabah mengajukan permohonan pembiayaan yang sudah dilengkapi dengan syarat-syarat lainnya bisa diserahkan kepada Account Officer atau jika nasabah langsung datang ke bank akan dilayani oleh Customer Service yang kemudian akan dialihkan kepada Account Officer. Syarat-syarat pengajuan pembiayaan:

\footnotetext{
${ }^{9}$ Marwansyah (Kepala Cabang), Wawancara, 16 Juni 2017

${ }^{10}$ Hikma Putriasa (Staff Accounting), Wawancara, 16 Juni 2017
} 
1. Fotocopy K'TP yang berlaku suami-istri rangkap 3;

2. Pas foto $4 \times 6$ suami-istri rangkap 3;

3. Fotocopy buku nikah rangkap tiga;

4. Fotocopy jaminan (BPKB/sertifikat) rangkap 3;

5. Fotocopy SK PNS terakhir rangkap 3 (untuk pembiayaan kolektif);

6. Slip gaji 3 bulan terakhir rangkap 3 (untuk pembiayaan kolektif);

7. Ada usaha yang berjalan minimal 1 tahun;

8. Surat keterangan usaha dari kelurahan/kades;

9. Membuat Rencana Anggaran Belanja (RAB) penggunaan uang tersebut;

10.Bukti DP untuk paket umrah, tagihan biaya pendidikan (untuk pembiayaan ijarah multijasa).

Sedangkan untuk pembiayaan Musyarakah ada syarat tambahan yang harus ada dalam surat permohonan, yaitu:

1. Anggaran dasar atau akta pendirian perusahaan;

2. Susunan pengurus/organisasi;

3. Izin-izin dari instansi yang berwenang (SIUP, SITU). ${ }^{11}$

b. Penyerahan Berkas ke Account Officer Penyerahan berkas kepada Account Officer ditujukan untuk menganalisis pembiayaan yang sesuai dengan kebutuhan nasabah. Pada tahap ini Account Officer juga bisa menilai kelayakan pengajuan pembiayaan.

Langkah kedua setelah pengajuan permohonan pembiayaan, berkas akan langsung diserahkan ke Account Officer untuk diidentifikasi kelayakannya. ${ }^{12}$ Setelah berkas sudah diserahkan oleh Costumer Service, Account Officerakan melihat pembiayaan apa yang sesuai untuk calon nasabah penerima fasilitas. Selanjutnya bagian administrasi pembiayaan akan melakukan kredit investigasi melalui riwayat kolektibilitas pembiayaan BPRS SAFIR serta taksasi jaminan.

c. Survei awal merupakan tahap yang ditujukan untuk memastikan data ataupun informasi yang disertakan nasabah dengan keadaan yang ada di lapangan.

Langkah ketiga setelah berkas diteliti oleh Account Officer, maka akan dilakukan survei awal oleh Account Officer yang bertanggung jawab terhadap

${ }^{11}$ Dokumentasi PT. BPRS SAFIR

${ }^{12}$ Marwansyah (Kepala Cabang), Wawancara, 16 Juni 2017 
pengajuan pembiayaan tersebut. ${ }^{13}$ Apabila Account Officer sudah memutuskan pembiayaan apa yang sesuai, tahap selanjutnya adalah survei awal. Tahap survei awal ini Account Officer akan melihat apakah berkas-berkas yang diserahkan sesuai dengan keadaan di lapangan, dan untuk melihat keadaan usaha serta objek yang dijadikan jaminan pembiayaan.Setelah dilakukan survei awal dan dinilai layak diberikan pembiayaan, tahap selanjutnya Account Officer akan membuat memo yang kemudian akan diserahkan kepada admin pembiayaan untuk diperiksa kelengkapan berkasnya. Jika berkas lengkap maka selanjutnya ialah survei lanjutan yang dilakukan oleh beberapa Account Officer.

d. Survei Lanjutan

Pada tahap survei lanjutan ditujukan untuk memutuskan pembiayaan agar tidak bersifat obyektif dari Account Officer yang bertanggung jawab. Survei lanjutan ini merupakan tahap evaluasi sebelum pembuatan memo ke pimpinan cabang.

Setelah survei awal dilakukan maka tahap selanjutnya ialah survei lanjutan yang dilakukan oleh beberapa Account Officer, yang selanjutnya akan diteruskan ke pimpinan cabang untuk keputusan pembiayaan. ${ }^{14}$

Survei lanjutan dilakukan oleh beberapa Account Officer, tujuan dilakukan survei lanjutan dengan beberapa Account Officeragar keputusan pembiayaan tidak obyektif. Jika para Account Officeryang melakukan survei sudah menyetujui pembiayaan, maka tahap selanjutnya ialah membuat memo yang ditujukan kepada pimpinan cabang untuk diputuskan pembiayaan diterima atau tidak.

d. Keputusan Pemberian Pembiayaan

Tahap keputusan pembiayaan merupakan tahap diputuskannya persetujuan suatu permohonan pembiayaan oleh pimpinan cabang. Pada tahap ini pimpinan cabang akan mengevaluasi dari beberapa tahap yang telah dilakukan oleh Account Officer yang bertanggung jawab melalui memo yang telah diajukan. Setelah memo dari Account Officer ada pada pimpinan cabang, maka pengajuan pembiayaan akan diputuskan diterima atau ditolak. ${ }^{15}$

Keputusan pemberian pembiayaan diberikan setelah beberapa unit staff BPRS SAFIR selesai melakukan review seperti Account Officer, dan bagian administrasi pembiayaan.Keputusan pembiayaan dilakukan oleh pimpinan cabang, jadi setelah pembiayaan diputuskan pimpinan cabang diterima maka tahap terakhir ialah menerbitkan surat keputusan pembiayaan.

${ }^{13}$ Hikma Putriasa (Staff Accounting), Wawancara, 16 Juni 2017

14 Yopi Mardani, (Staff Accounting), Wawancara, 16 Juni 2017

${ }^{15}$ Marwansyah (Kepala Cabang), Wawancara, 16 Juni 2017 
e. Realisasi Keputusan

Realisasi keputusan merupakan tehap pencairan pembiayaan setelah semua persyaratan dipenuhi dan beberapa tahap dilewati. Realisasi keputusan ini akan dilakukan saat dokumen jaminan diserahkan ke bank setelah di tandatangani. Langkah akhir dari prosedur pembiayaan ialah realisasi keputusan dari pimpinan cabang, saat realisasi keputusan ini calon nasabah penerima fasilitas pembiayaan juga akan menandatangani akta pengikatan jaminan. ${ }^{16}$ Pada tahap ini persetujuan bank atas permohonan pembiayaan yang diajukan oleh calon nasabah penerima fasilitas yang dimuat dalam surat keputusan pembiayaan masih bersifat penawaran dari bank kepada calon nasabah penerima fasilitas. Karena pada intinya surat keputusan pembiayaan belum mengikat bank dengan calon nasabah penerima fasilitas pembiayaan. Apabila calon nasabah penerima fasilitas menyetujui syarat-syarat yang tertera dalam surat keputusan pembiayaan, maka calon nasabah penerima fasilitas pembiayaan mengembalikan kopi surat keputusan pembiayaan yang telah ditandatangani di atas materai. Selanjutnya masuk pada tahap pengikatan jaminan pembiayaan, penandatanganan akta pengikatan jaminan dilakukan bersamaan dengan penandatanganan akad pembiayaan. Artinya penandatanganan perjanjian pengikatan jaminan tersebut paling lambat harus dilakukan sebelum pencairan pembiayaan dilakukan. Apabila penandatanganan perjanjian jaminan mendahului akad pembiayaan maka dikhawatirkan akan menimbulkan cacat yuridis. Namun jika penandatanganan perjanjian jaminan belum dilakukan setelah pencairan pembiayaan dilakukan, maka fasilitas pembiayaan tersebut tidak aman.

Dari ketiga akad pembiayaan yang ditawarkan oleh BPRS SAFIR yang paling diminati nasabah ialah pembiayaan Murabahah dan pembiayaan Musyarakah. Sedangkan pembiayaan Ijarah Multijasa masih sedikit diminati nasabah, karena pembiayaan dengan akad ini masih baru ditawarkan dan terhitung belum mencapai satu tahun sejak pertama kali di aplikasikan. ${ }^{17}$

Berdasarkan hasil wawancara di atas, dapat disimpulkan bahwa pembiayaan yang memiliki andil besar dalam operasional BPRS SAFIR saat ini ialah pembiayaan Murabahah dan pembiayaan Musyarakah.

Hal ini sudah terlihat jelas dari yang dipaparakan narasumber d i atas, karena pembiayaan Ijarah multijasa baru diaplikasikan dan pengenalan kepada masyarakat masih belum gencar dilakukan. Perkembangan pembiayaan BPRS SAFIR dalam 5 tahun terakhir tergambar dalam diagram di bawah ini:

16 Yopi Mardani, (Staff Accounting), Wawancara, 16 Juni 2017

${ }^{17}$ Hikma Putriasa (Staff Accounting), Wawancara, 16 Juni 2017 
Gambar 1.1 Perkembangan Pembiayaan PT. BPRS SAFIR

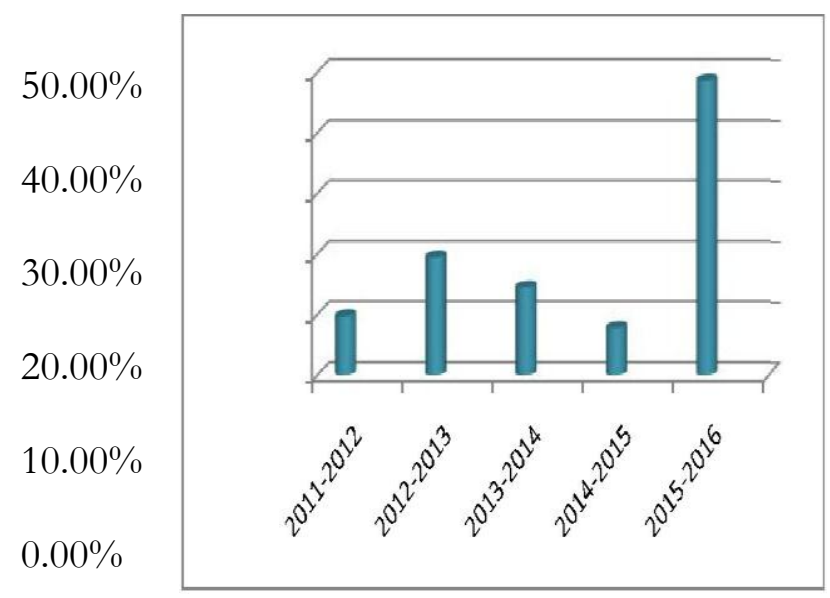

Di BPRS SAFIR perkembangan pembiayaan pada tiap tahun nya tidak bisa diprediksi akan me ngalami peningkatan ataupun penurunan. Seperti yang dilihat pada diagram di atas bahwa setiap tahun pembiayaan di BPRS SAFIR tidak tetap pada satu titik. Pada rentang tahun 2011-2012 pembiayaan pada BPRS SAFIR berada pada presentase 9,7\% atau sebesar Rp 2.000.000.000 yang disalurkan, pada tahun 2012-2013 meningkat ke presentase 19,41\% atau sebesar Rp 2.900.000.000 yang disalurkan, kemudian di rentang tahun 20132014 pembiayaan di BPRS SAFIR menurun sebesar 4,85\% sehingga turun kepresentase $14,56 \%$ atau sebesar $\mathrm{Rp} 3.100 .500 .000$ pembiayaan yang disalurkan.

Pada tahun 2014-2015 merupakan titik terendah perkembangan pembiayaan yang dialami oleh BPRS SAFIR, karena pada rentang tahun ini pembiayaan ada di presentase $7,77 \%$ dari pembiayaan yang disalurkan sebesar Rp.2.800.000.000, dan pada tahun 2015-2016 perkembangan pembiayaan meningkat drastis ke presentase $48,54 \%$ dengan pembiayaan yang disalurkan sebesar Rp.3.295.800.000.

Untuk perkembangan pembiayaan, kami tidak bisa memprediksi apakah akan meningkat atau menurun tiap tahunnya. Seperti yang sudah tergambar dalam perkembangan pembiayaan dari tahun 2011 sampai 2016 tersebut, pembiayaan bisa saja meningkat tajam ataupun sebaliknya. Upaya yang kami lakukan ialah untuk mencegah pembiayaan bermasalah muncul, dengan berbagai tindakan mitigasi yang kami gunakan. ${ }^{18}$

Berdasarkan hasil wawancara di atas dapat diketahui bahwa BPRS

${ }^{18}$ Hikma Putriasa (Staff Accounting), Wawancara, 16 Juni 2017 
SAFIR hanya berupaya memaksimalkan pembiayaan sesuai dengan target awal, sedangkan untuk pencapaian posisi ke tingkat tertentu BPRS SAFIR tidak bisa menetapkan. Karena pada dasarnya perkembangan pembiayaan ditentukan oleh keinginan masyarakat akan pembiayaan dan kemampuan pihak bank dalam menyeleksi calon nasabah penerima fasilitas, sehingga naik turunnya pembiayaan setiap tahun tidak bisa diprediksi sejak awal.

\section{Risiko Pembiayaan BPRS SAFIR Cabang Curup Kabupaten Rejang Lebong}

\section{Risiko Kredit}

Risiki kredit adalah risiko dari kemungkinan terjadinya kerugian bank sebagai akibat dari tidak dilunasinya kredit yang diberikan bank kepada debitur maupun counterparty lainnya. ${ }^{19}$ Dalam kasus risiko kredit, biasanya disebabkan dari pihak nasabah penerima fasilitas pembiayaan.

Untuk risiko kredit, ini merupakan risiko yang muncul dari pihak nasabah sendiri. Dalam masalah ini bank tidak langsung mengambil tindakan keras kepada nasabah, melainkan melakukan pengkajian ulang apa yang menjadi kendala nasabah untuk membayar kreditnya kembali. Tindakan utamanya ialah mengidentifikasi permasalahan yang ada pada usaha nasabah. ${ }^{20}$

Berdasarkan hasil wawancara di atas risiko kredit merupakan kendala yang berasal dari pihak nasabah, karena risiko kredit ini muncul dari perubahan kondisi ekonomi nasabah ataupun watak dari nasabah sendiri. Risiko kredit memiliki andil besar terhadap pembiayaan bermasalah yang muncul di BPRS SAFIR, karena semakin besar risiko kredit maka otomatis pembiayaan bermasalah yang muncul akan semakin besar. Dalam mengembangkan perekonomian, khususnya pengusaha menengah ke bawah BPRS mengambil andil besar didalamnya.

Fungsi dari BPRS sendiri ialah untuk meningkatkan ekonomi masyarakat menengah ke bawah. Sehingga disini bank sangat teliti dalam menganalisis pembiayaan yang diajukan calon nasabah penerima fasilitas pembiayaan agar tidak menimbulkan masalah di kemudian hari karena sudah diidentifikasi sejak awal. $^{21}$

Berdasarkan hasil wawancara di atas bisa diketahui walaupun fungsi BPRS untuk meningkatkan perekonomian masyarakat menengah ke bawah,

19 Umer Chapra dan Habib Ahmed, Corporate Governance Lembaga Kenangan Syariah, (Jakarta: Sinar Grafika Offset, 2008), hal.75

${ }^{20}$ Marwansyah (Kepala Cabang), Wawancara, 16 Juni 2017

${ }^{21}$ Marwansyah (Kepala Cabang), Wawancara, 16 Juni 2017 
namun tindakan BPRS SAFIR dalam mengelola risiko sangat diterapkan. Contohnya mitigasi risiko yang dilakukan BPRS SAFIR pada awal pembiayaan dengan melakukan analisis pembiayaan, sehingga risiko bisa diidentifikasi dari awal. Pada sisi lain, pembinaaan pengusaha menengah ke bawah diarahkan untuk meningkatkan kemampuan pengusaha tersebut menjadi lebih baik. Sehingga harus disadari pengembangan usaha menghadapi beberapa kendala, seperti tingkat kemampuan, keterampilan, keahlian, manajemen sumber daya manusia, kewirausahaan, pemasaran dan keuangan. Lemahnya manajerial dan sumber daya kebanyakan mengakibatkan pengusaha tingkat menengah ke bawah tidak mampu menjalankan usahanya dengan baik. Secara spesifik ada beberapa masalah yang ada pada usaha menengah ke bawah yang sering terjadi, diantaranya:

a. Usaha calon nasabah penerima fasilitas memiliki prospek usaha, namun tidak memiliki agunan yang cukup;

b. Usaha calon nasabah penerima fasilitas memiliki prospek usaha, namun kemampuan teknis dan manjerialnya kurang;

c. Usaha calon nasabah penerima fasilitas berhasil memperoleh pembiayaan, namun pembiayaan tersebut tidak cukup untuk memenuhi rencana pengembangan.

Penyebab kegagalan nasabah penerima fasilitas pembiayaan dalam mengefektifkan pembiayaan bank, yaitu:

a. Nilai kredit tidak cocok dengan kebutuhan pembiayan yang terlalu besar;

b. Biaya kredit lebih besar dari kredit yang akan atau telah diperoleh;

c. Kurang disiplin;

d. Menghadapi kesulitan karena keterbatasan kemampuan teknis dan manajerial;

e. Perubahan situasi ekonomi yang terjadi setelah pembiayan.

\section{Risiko Strategik}

Risiko strategik adalah risiko yang muncul akibat ketidaktepatan dalam pengambilan atau pelaksanaan suatu keputusan strategik serta kegagalan mengantisipasi perubahan lingkungan bisnis. Risiko strategik ini disebabkan kesalahan dari pihak bank yang tidak mampu menyesuaikan rencana dengan keadaan eksternal bank.

Selain risiko kredit, risiko yang diutamakan di BPRS SAFIR adalah risiko strategik, karena secara tidak langsung risiko stategik berpengaruh besar 
terhadap kelangsungan usaha bank sendiri. ${ }^{22}$ Berdasarkan hasil wawancara di atas risiko strategik memiliki pengaruh yang besar terhadap kelangsungan usaha bank, karena risiko strategik ini bank memilih langkah awal terhadap strategik yang akan dipilih bank dalam menjalankan kegiatan bank untuk beberapa waktu ke depan. Termasuk di dalam risiko strategik ini penerapan manajamen risiko dan analisis pembiayaan. Oleh karena itu penerapan manajemen risiko dan analisis pembiayaan sebelum pemberian pembiayaan dilakukan sangat berpengaruh terhadap risiko strategik yang akan diterima oleh bank. Karena dengan adanya 2 hal ini, bank akan tahu seberapa jauh jangkauan bank dalam mengelola risiko.

\section{a. Penerapan Manajemen Risiko}

Pada dasarnya manajemen risiko meningkatkan nilai perusahaan sekaligus mendukung pertumbuhan ekonomi dengan menurunkan biaya modal dan mengurangi ketidakpastian aktivitas sosial. Penerapan manajemen risiko oleh perusahaan bertujuan untuk mengidentifikasi risiko perusahaan, mengukur dan mengatasinya pada level toleransi tertentu. Manajemen risiko pada BPRS SAFIR sudah ada pada saat BPRS SAFIR berdiri, namun manajemen risiko ini lebih dirasa penting ketika sudah muncul pembiayaan bermasalah (Non Performing Financing). Sehingga pada saat tahun kedua berjalan manajemen risiko menjadi salah satu faktor penting pada keputusan pembiayaan. $^{23}$

Berdasarkan hasil wawancara di atas, bisa diketahui bahwa manajemen risiko di BPRS SAFIR sudah ada pada saat BPRS berdiri. Namun pada tahun pertama operasional berjalan, manajemen risiko belum menjadi perhatian utama BPRS SAFIR. Manajemen risiko menjadi perhatian utama dan faktor penting pada keputusan pembiayaan yakni pada saat tahun kedua BPRSSAFIR mulai berjalan dan mulai muncul pembiayaan bermasalah.

\section{b. Analisis Pembiayaan}

Faktor lain yang mempengaruhi risiko strategi pembiayaan terletak pada analisis pembiayaan, yaitu analisis 5C: Character, Capacity; Capital; Conditional; dan Collateral.

Penerapan 5C dalam analisis pembiayaan di BPRS SAFIR sangat dilakukan, karena pada tahap analisis inilah bank bisa menilai risiko yang akan diminimalisir dari awal. Namun yang lebih diutamakan pada BPRS SAFIR ialah analisis karakter dan usaha dari nasabah yang mengajukan pembiayaan.

${ }^{22}$ Hikma Putriasa (Staff Accounting), Wawancara, 16 Juni 2017
${ }^{23}$ Yopi Mardani, (Staff Accounting), Wawancara, 16 Juni 2017 
Pada tahap analisis pembiayaan inilah bank bisa mengetahui perubahan yang terjadi di luar bank, yang bisa diketahui ketika melakukan analisis pembiayaan. ${ }^{24}$

Berdasarkan hasil wawancara di atas prinsip analisis $5 C$ di BPRS SAFIR sangat didisiplinkan pada karyawan, hal ini sangat penting menurut penulis karena jika para karyawan sudah disiplin. dengan prinsip analisis ini maka secara tidak langsung risiko yang ada akan bisa terminimalisir dan bahkan bisa dihindari dari awal. Dengan prisnip analisis $5 C$ ini bank bisa mengidentifikasi keadaan, baik keadaan nasabah, maupun keadaan luar bank yang akan berpengaruh dalam proses pembiayaan.

1) Character

Penilaian karakter nasabah adalah untuk mengetahui itikad baik nasabah untuk memenuhi kewajibannya dan untuk mengetahui moral, watak, maupun sifat-sifat pribadi yang positif dan kooperatif.

2) Capacity

Yaitu kemampuan nasabah untuk menjalankan usaha guna memperoleh laba yang diharapkan sehingga dapat mengembalikan pembiayaan yang diterima.

3) Capital

Menilai jumlah modal sendiri yang diinvestasikan oleh nasabah dalam usahanya termasuk kemampuan untuk menambah modal apabila diperlukan sejalan dengan perkembangan usahanya.

4) Conditional

Kondisi usaha nasabah yang dipengaruhi oleh situasi sosial dan ekonomi. Kondisi dipengaruhi antara lain peraturan-peraturan pemerintah, situasi politik dan perekonomian dunia, kondisi ekonomi yang mempengaruhi pemasaran, produk, dan keuangan.

5) Collateral

Asset atau benda yang diserahkan nasabah sebagai agunan terhadap pembiayaan yang telah diterimanya. Collateral harus dinilai oleh bank untuk mengetahui risiko kewajiban finasial nasabah kepada bank. Penilaian jenis jaminan meliputi jenis, lokasi, bukti kepemilikan, dan status hukumnya. Penilaian terhadap collateral dapat ditinjau dari dua segi, yaitu:

a) Segi ekonomis, yaitu nilai ekonomis dari benda yang akan diagunkan;

${ }^{24}$ Hikma Putriasa (Staff Acounting), Wawancara, 16 Juni 2017 
b) Segi yuridis, yaitu menilai apakah agunan tersebut memenuhi syaratsyarat yuridis untuk dipakai sebagai agunan. ${ }^{25}$

\section{Mitigasi Risiko Pembiayaan Pada PT. BPRS SAFIR Cabang Curup Kabupaten Rejang Lebong}

Semakin tinggi tingkat risiko pembiayaan yang dihadapi BPRS SAFIR membutuhkan pengelolaan risiko yang tepat dan lebih baik untuk meminimalisir risiko pembiayaan.

Semua risiko menjadi prioritas disini, namun yang lebih diutamakan dari risiko lainnya adalah risiko kredit dan risiko strategik. Kedua risiko ini bersumber dari 2 pihak yakni pihak bank dan nasabah sendiri, sehingga butuh usaha maksimal untuk meminimalisir dampak dari risiko yang akan muncul. BPRS SAFIR memilih solusi mitigasi risiko dengan menghindari serta mengurangi risiko yang akan muncul. Jika nasabah yang mengajukan pembiayaan dengan usaha yang masih tergolong baru, maka bank tidak akan menerima pembiayaan tersebut. Ini salah satu cara untuk menghindari serta mengurangi risiko yang akan timbul secara langsung, dan cara menghindari serta mengurangi risiko ini dianggap paling sesuai dengan prinsip syariah. ${ }^{26}$

Berdasarkan hasil wawancara di atas tindakan mitigasi yang dilakukan oleh BPRS SAFIR ada 2, yakni menghindari risiko dan mengurangi risiko. Tindakan mitigasi ini adalah mitigasi yang sesuai dengan prinsip syariah, karena pengelolaan risiko dilakukan sendiri oleh pihak bank tanpa mengalihkan ke pihak lain ataupun membebankan seluruh risiko kepada nasabah yang bersangkutan. Dalam pembuatan rencana mitigasi pada BPRS SAFIR sudah tercantum dalam SOP dan Peraturan Perusahaan.

Semua karyawan yang ada di BPRS SAFIR terlibat dalam pembuatan rencana mitigasi, seperti Account Officer, Admin Pembiayaan, serta pimpinan cabang yang memutuskan pembiayaan. Dan sudah ada SOP dan peraturan perusahaan yang menjadi acuan, meskipun saat ini SOP sedang dirincikan ulang. ${ }^{27}$

Berdasarkan hasil wawancara di atas menjelaskan bahwa pembuatan rencana mitigasi melibatkan semua pihak yang ada di BPRS SAFIR. Sehingga semua pihak bisa mengeluarkan pendapat terhadap hal yang dirasa penting dan perlu untuk dijadikan patokan saat menyusun rencana mitigasi kedepannya.

\footnotetext{
${ }^{25}$ Dokumentasi PT. BPRS SAFIR

${ }^{26}$ Hikma Putriasa (Staff Accounting), Wawancara, 16 Juni 2017

${ }^{27}$ Yopi Mardani, (Staff Accounting), Wawancara, 16 Juni 2017
} 
Langkah-langkah mitigasi risiko pembiayaan yang dilakukan BPRS SAFIR, antara lain sebagai berikut:

\section{Menghindari Risiko}

Mitigasi risiko BPRS SAFIR dengan menghindari risiko ialah dengan melakukan evaluasi mendalam pada usaha dan karakter nasabah, karena dengan melakukan evaluasi secara mendalam bank bisa menilai calon nasabah penerima fasilitas pembiayaan memiliki usaha yang berkualitas serta watak yang baik atau tidak sehingga tidak akan mendatangkan kerugian bagi pihak bank di kemudian hari.

Tahap evaluasi mendalam terhadap usaha dan karakter nasabah sangat didisiplinkan BPRS SAFIR pada karyawan, karena jika usaha nasabah berjalan baik dan lancar namun karakter nasabah sulit dan sangat minim kesadaran untuk menyicil pengembalian pembiayaan maka akan menimbulkan pembiayaan bermasalah, begitu juga sebaliknya. ${ }^{28}$

Berdasarkan hasil wawancara di atas, penulis bisa menjelaskan bahwa tindakan mitigasi dengan menghindari risiko adalah dengan melakukan evaluasi mendalam terhadap usaha dan karakter nasabah. Hal ini juga bisa memperkecil tingkat pembiayaan bermasalah yang muncul di BPRS SAFIR, dan bisa menghindari risiko yang akan terjadi di kemudian hari. Usaha dan karakter nasabah sangat memiliki andil besar terhadap kelangsungan pembiayaan bank, karena usaha dan karakter saling memberikan timbal balik. Pada pembiayaan Murabahah dan Musyarakah pengikatan pembiayaan terletak pada usaha yang dibiayai, dan sumber pendapatan utama bank berasal dari usaha yang dibiayai. Sedangkan pada pembiayaan Ijarab multijasa, pengikatan pembiayaan terletak dari penggunaan pembiayaan serta karakter dari nasabah tersebut.

BPRS SAFIR dalam hal penyaluran pembiayaan tidak begitu saja menyalurkan pembiayaan tetapi harus disesuaikan antara akad dengan pembiayaan yang diajukan. Penetapan pembiayaan dengan akad yang diajukan akan ditinjau kembali oleh BPRS SAFIR dan menyesuaikan dengan tujuan serta kebutuhan nasabah, jika sesuai bank akan mempertimbangkannya melalui analisis kelayakan pembiayaan.

Pihak bank harus mengevaluasi secara mendalam terhadap usaha dan karakter nasabah yang dibiayai melalui prosedur yang telah ditetapkan. Untuk mengevaluasi usaha dan karakter nasabah seperti yang telah dijelaskan sebelumnya BPRS SAFIR menggunakan konsep 5C serta survei langsung ke

${ }^{28}$ Marwansyah (Kepala Cabang), Wawancara, 16 Juni 2017 
tempat usaha nasabah yang dilakukan oleh Account Officer. Langkah survei ke tempat usaha nasabah yang dilakukan oleh. BPRS SAFIR bertujuan untuk memastikan data yang diserahkan nasabah pada saat mengajukan pembiayaan sama dengan kondisi yang ada. Survei lapangan ini dilakukan 2 tahap, yakni yang pertama survey yang dilakukan oleh Account Officer yang sejak awal menghandle pembiayaan tersebut. Kemudian tahap kedua ialah survei yang dilakukan dengan beberap Account Officer lainnya, sehingga keputusan penyaluran pembiayaan tidak bersifat obyektif.

Untuk pengajuan pembiayaan disini tidak bisa sembarangan, syarat yang harus dipenuhi oleh nasabah ialah usaha yang akan dibiayai sudah berjalan dan aktif melakukan transaksi keuangan selama 1 tahun. Hal ini dikarenakan kami belajar dari pengalaman pada tahun-tahun pertama, banyak nasabah yang bermasalah dan menimbulkan pembiayaan bermasalah ialah nasabah yang baru akan merintis usaha. ${ }^{29}$

Berdasarkan hasil wawancara di atas, tahun pertama operasional di BPRS SAFIR sangat dijadikan acuan dalam mengambil tindakan selanjutnya. Beberapa persyaratan untuk mengajukan pembiayaan juga menjadi faktor penting untuk menghindari risiko, seperti usaha nasabah yang harus berjalan dalam kurun waktu minimal satu tahun. Dengan usaha nasabah yang sudah berjalan satu tahun, bisa menjadi indikasi bahwa usaha nasabah tersebut lancar dan memiliki manajemen yang baik dalam menjalankan usahanya. Syarat usaha nasabah harus sudah berjalan selama 1 tahun ini adalah salah satu usaha bank untuk menilai seberapa baik pendapatan usaha, hal ini akan dilihat BPRS SAFIR melalui mutasi rekening nasabah yang dibiayai dan terlihat riwayat kolektibilitas pembiayaan BPRS SAFIR. Dengan langkah ini, BPRS SAFIR sudah menjalankan mitigasi risiko dengan menghindari risiko tersebut.

\section{Mengurangi Risiko}

\section{a. Penetapan syarat-syarat tertentu untuk masing-masing pembiayaan yang harus dipenuhi calon nasabah penerima fasilitas}

Persyaratan berbagai bentuk pembiayaan sudah mempunyai ketentuan masing-masing sehingga pada prinsipnya sama, namun ada sebagian kecilnya yang berbeda untuk menilai pembiayaan apa yang diinginkan, sebagaimana yang dijelaskan oleh pimpinan cabang.

Untuk setiap pengajuan permohonan pembiayaan di sini pasti harus melengkapi syarat-syarat yang sudah ditetapkan oleh pihak bank.

${ }^{29}$ Hikma Putriasa (Staff Accounting), Wawancara, 16 Juni 2017 
Syarat-syarat untuk setiap pembiayaan sebagian besar hampir sama, namun ada syarat-syarat khusus yang harus dipenuhi untuk masing-masing pembiayaan. ${ }^{30}$

Berdasarkan hasil wawancara di atas, setiap pembiayaan yang ada di BPRS SAFIR memiliki syarat-syarat khusus yang harus dipenuhi saat calon nasabah penerima fasilitas pembiayaan akan mengajukan permohonan pembiayaan. Tindakan BPRS SAFIR dalam hal ini bisa mengurangi risiko, karena dengan terpenuhinya syarat khusus yang sudah ditetapkan pihak bank sama artinya calon nasabah mampu memenuhi kewajibannya di kemudian hari dengan bukti terpenuhinya syarat khusus tersebut. BPRS SAFIR dalam produk pembiayaan menerapkan syaratsyarat tertentu pada masing-masing pembiayaan. Pada pembiayan Murabahah dibagi menjadi 2 segmen, yaitu pembiayaan umum dan pembiayaan kolektif. Pembiayaan umum pada BPRS SAFIR diperuntukkan untuk masyarakat umum, sedangkan pembiayaan kolektif atau pembiayaan bersama diperuntukkan untuk PNS. Pada pembiayaan Murabahah, jika pinjaman di bawah 10 juta maka agunan yang diberikan bisa berupa BPKB kendaraan bermotor, dan jika pinjaman di atas 10 juta agunan berupa sertifikat tanah atau bangunan.

Murabahah pembiayaan kolektif bisa diajukan jika dalam satu instansi minima 12 orang yang memberikan permohonan pembiayaan. Serta menyertakan SK PNS dan slip gaji 3 bulan terakhir. Walaupun yang mengajukan pinjaman 2 orang, namun jika disetujui pembiayaan yang akan dicairkan tidak dibagi dua. Artinya pembiayaan yang dicairkan sesuai dengan jumlah yang diajukan di awal.Berdasarkan hasil wawancara di atas, dengan memberikan jumlah minimal calon nasabah penerima fasilitas yang mengajukan pembiayaan pada pembiayaan Murabahah pembiayaan kolektif, bank bisa mengurangi risiko dari awal. Seperti yang telah dijelaskan di atas, pembiayaan Murabahah pembiayaan kolektif ditujukan atas nama instansi, sehingga secara tidak langsung bank bisa memonitor nasabah penerima fasilitas dalam satu langkah melalui intsansi yang bersangkutan. Pembiayaan Musyarakah ditujukan untuk perusahaanperusahaan yang sedang atau ingin menjalankan proyek, seperti CV dan PT. Sehingga pada saat pelengkapan berkas, harus ada SIUP, dan SITU. Jika pembiayaan yang diajukan untuk proyek adalah pembiayaan yang akan berjalan maka BPRS SAFIR akan memberikan 25\% dari total dana yang diajukan pada tahap pertama, kemudian saat proyek tersebut berlajan

${ }^{30}$ Marwansyah (Kepala Cabang), Wawancara, 16 Juni 2017 
BPRS SAFIR harus mengetahui perkembangan dari proyek tersebut. Pada saat proyek telah berjalan BPRS SAFIR akan memberikan 50\% dari total dana yang diajukan. Dan pada tahap ketiga, BPRS SAFIR akan memberikan 25\% dari total dana yang diajukan. ${ }^{31}$

Sedangkan untuk pembiayaan Ijarah multijasa diperuntukkan untuk dana talangan umrah, biaya pendidikan, talangan pernikahan, serta rincian biaya pengobatan. Tidak ada syarat khusus dalam pembiayaan Ijarah multijasa, sama dengan pembiayaan yang lain harus memiliki usaha minimal sudah berjalan 1 tahun dan menyertakan agunan. Besaran Plafond setiap pembiayaan sama yakni 5-100 juta, tergantung dengan jumlah yang diajukan serta jenis usaha dari nasabah tersebut.

Nasabah yang mengajukan pembiayaan harus memiliki usaha minimal yang sudah berjalan selama 1 tahun, hal ini ditujukan untuk menghindari pembiayaan bermasalah (Non Performing Financing). Dan khusus untuk pembiayaan Musyarakah, usaha nasabah harus memiliki cash flow yang stabil pada transaksi keuangannya. ${ }^{32}$

Berdasarkan hasil wawancara di atas, BPRS SAFIR sangat berhati-hati dalam hal pemberian pembiayaan. Dilihat dari usaha yang harus berjalan minimal 1 tahun, dan harus memiliki cash flow yang stabil pada transaksi keuangannya, ini memperlihatkan bagaimana BPRS SAFIR sangat memperhatikan kualitas usaha dari calon nasabah penerima fasilitas pembiayaan. Langkah BPRS SAFIR ini merupakan langkah yang dilakukan diawal untuk memproteksi bank dari risiko.

\section{b. Pengikatan Jaminan}

Penyaluran dana berdasarkan prinsip syariah oleh bank syariah dan Unit Usaha Syariah (UUS) mengandung risiko kegagalan atau kemacetan dalam pelunasannya sehingga dapat berpengaruh terhadap kesehatan bank syariah dan UUS, sebagaimana yang diatur dalam Pasal 37 Ayat 1 UndangUndang Nomor 21 Tahun 2008 tentang Perbankan Syariah. ${ }^{33}$

Berdasarkan Pasal 37 Ayat 1 Undang-Undang Nomor 21 Tahun 2008 tentang Perbankan Syariah tersebut maka untuk mengamanatkan dana yang disalurkan oleh bank syariah tersebut maka diperlukan jaminan atau agunan yang memiliki nilai ekonomis yang dapat dieksekusi guna mengantisipasi jika nasabah wanprestasi.

Jaminan yang diberikan nasabah menjadi salah satu pertimbangan bank dalam memutuskan pembiayaan, karena fungsi jaminan disini untuk

\footnotetext{
${ }^{31}$ Dokumentasi PT. BPRS SAFIR

32 Marwansyah (Kepala Cabang), Wawancara, 16 Juni 2017

${ }^{33}$ http://repository.usu.ac.id/, 02 Juli 2017
} 
mencover pembiayaan nasabah tersebut. Pada BPRS SAFIR jaminan merupakan jalan keluar kedua atau jalan keluar terakhir saat nasabah tidak melaksanakan kewajibannya dengan baik, sehingga jaminan yang diberikan di awal akan dicairkan untuk melunaskan kewajibannya. ${ }^{34}$

Berdasarkan hasil wawancara di atas, pengikatan jaminan pada BPRS SAFIR merupakan langkah antisipasi dari pihak bank jika terjadi gagal bayar ketika telah dilakukan evaluasi ulang pembiayaan, nasabah sudah tidak memiliki usaha lagi dan tidak kooperatif lagi dalam menyelesaikan pembiayaan. Pada setiap pembiayaan pada BPRS SAFIR, bank menetapkan bahwa diharuskan adanya jaminan berupa fixed asset (tanah, bangunan), dan movable asset (kendaraan).

\section{c. Monitoring Berkala}

Monitoring merupakan kunci utama dalam pengelolaan pembiayaan, baik pembiayaan Murabahah, Musyarakah, dan Ijarah Multijasa yang dilakukan pasca dropping pembiayaan, termasuk pada pengawasan dan pembinaan. Monitoring pada BPRS SAFIR akan dilakukan secara berkala tergantung dengan jenis pembiayaan.

Pada tahap monitoring pihak bank akan selalu menjaga komunikasi dengan nasabah, sehingga memudahkan bank dalam mengidentifikasi jika ada hal yang akan menimbulkan masalah. Monitoring ini sendiri merupakan mitigasi utama yang sangat penting setelah pencairan pembiayaan, dengan monitoring yang lebih ketat bank bisa mencegah munculnya pembiayaan bermasalah. $^{35}$

Berdasarkan hasil wawancara di atas, BPRS SAFIR selalu menjaga komunikasi dengan pihak nasabah setelah proses pencairan pembiayaan sebagai salah satu startegi monitoring. Langkah ini bisa menjadi acuan pihak bank, karena dengan terjaganya komunikasi dengan nasabah maka bank akan mengetahui seberapa besar perkembangan usaha nasabah, dan seberapa besar pertambahan pendapatan dari nasabah tersebut. Monitoring yang dilakukan antara lain memantau transaksi keuangan nasabah dan bukti keuangan penggunaan dana berdasarkan rencana anggaran belanja yang dimaksudkan di awal pembiayaan, memberikan pemahaman dan memantau kewajiban nasabah dalam melaporkan laporan pendapatannya setiap bulan, mengidentifikasi ketidaktepatan pembayaran, melakukan pembinaan ketika terjadi penurunan pada usaha nasabah terutama yang terkait dengan pendapatan, dan menangani pembiayaan bermasalah tepat waktu.

\footnotetext{
${ }^{34}$ Hikma Putriasa (Staff Accounting), Wawancara, 16 Juni 2017

35 Yopi Mardani, (Staff Accounting), Wawancara, 16 Juni 2017
} 


\section{PENUTUP}

Berdasarkan pembahasan pada bab-bab sebelumnya dan merujuk pada hasil penelitian yang dilakukan penulis, maka dapat disimpulkan beberapa hal sebagai berikut: Pertama, Prosedur pembiayaan di BPRS SAFIR ada beberapa tahap, Pertama mengajukan permohonan pembiayaan yang sudah dilengkapi dengan syarat-syarat yang telah ditetapkan; Kedua penyerahan berkas ke Account Officer untuk diidentifikasi; Ketiga survei awal yang dilakukan oleh Account Officer Account Officer yang bertanggung jawab atas permohonan pembiayaan; Keempat survey lanjutan yang dilakukan dengan beberapa Account Officer, elima keputusan pemberian pembiayaan yang dilakukan oleh pimpinan cabang setelah memperoleh memo dari Account Officer tentang pembiayaan yang diajukan; Keenam realisasi keputusan dari pihak bank kepada nasabah, pada saat realisasi keputusan pembiayaan ini calon nasabah penerima fasilitas pembiayaan juga menandatangani akta perjanjian jaminan.

Kedua, Risiko yang dihadapi BPRS SAFIR berkaitan dengan risiko kredit dan risiko strategik. Umumnya risiko-risiko ini muncul karena permasalahan masingmasing pihak, risiko kredit muncul karena kesalahan dari pihak nasabah. Kesalahan ini bisa disebabkan oleh beberapa hal, karena perubahan keadaanekonomi atau watak dari nasabah yang tidak memiliki itikad baik lagi untuk melunasi kewajibannya. Sedangkan risiko strategik muncul karena kesalahan pihak bank, risiko strategik sangat memiliki pengaruh besar bagi kelangsungan usaha bank. Jika bank salah langkah dalam memilih strategic yang tidak sesuai dengan kondisi eksternal bank, maka apa pun yang direncanakan bank di awal tidak akan berjalan dengan baik. Karena kedua risiko ini memberikan dampak yang besar BPRS SAFIR selalu memaksimalkan kemampuan untuk meminimalisir kedua risiko ini.

Ketiga, Tindakan mitigasi risiko pembiayaan BPRS SAFIR ialah menghindari dan mengurangi risiko. Mitigasi menghindari risiko dilakukan dengan melakukan evaluasi mendalam terhadap usaha dan karakter calon nasabah penerima fasilitas pembiayaan. Kemudian mitigasi kedua yang dilakukan BPRS SAFIR yaitu mengurangi risiko dengan penetapan syarat-syarat tertentu untuk masing-masing pembiayaan yang harus dipenuhi calon nasabah penerima fasilitas; pengikatan jaminan berupa fixed asset dan movable asset; dan melakukan monitoring berkala.

\section{DAFTAR PUSTAKA}

Chapra, Umer dan Habib, Ahmed, Corporate Governance Lembaga Kenangan Syariah, (Jakarta: Sinar Grafika Offset, 2008)

Dokumentasi PT. BPRS SAFIR 
212 |Al-Falah: Journal of Islamic Economics, Vol.3, No.2, 2018

Karim, Adiwarman, Bank Islam (Analisis Fiqh dan Kenangan), (Jakarta: PT Raja Grafindo Persada, 2004)

Muhammad, Manajemen Pembiayaan Bank Syariah, (Yogyakarta: Unit Penerbit dan Percetakan, 2005).

Prasastinah Usanti, Trisadini, Pengelolaan Risiko Pembiayaan di Bank Syariah, (Fakultas Hukum Airlangga, Vol.3 No.2)

Rivai, Veithzhal, Basir, Sofyan, dkk, Commercial Bank Management Manajemen Perbankan) Dari Teori ke Praktik, (Jakarta: PT. Raja Grafindo Persada, 2012).

Safariyani, Risa, Manajemen Risiko Pembiayaan Al-Istishna' Pada BPRS Amanah Ummah, Leuwiliang Bogor, Skripsi Fakultas dan Hukum UIN Syarif Hidayatullah 